\title{
Hepatoprotective effect of Solanum surattense leaf extract against chemical- induced oxidative and apoptotic injury in rats
}

Mohammad K. Parvez ${ }^{1 *}$, Mohammed S. Al-Dosari ${ }^{1}$, Ahmed H. Arbab ${ }^{1,2}$, Perwez Alam ${ }^{1}$, Mansour S. Alsaid ${ }^{3}$ and Azmat A. Khan ${ }^{4}$

\begin{abstract}
Background: Of over 35 Saudi plants traditionally used to treat liver disorders, majority still lack scientific validations. We therefore, evaluated the anti-oxidative, anti-apoptotic and hepatoprotective potential of Solanum surattense leaves total ethanol-extract (SSEE).

Methods: The cytoprotective (4,5-dimethylthiazol-2-yl-2,5-diphenyltetrazolium bromide/ MTT assay) and anti-apoptotic (caspase-3/7) potential of SSEE (25-200 $\mu \mathrm{g} / \mathrm{mL}$ ) were assessed in cultured HepG2 cells against dichlorofluorescein (DCFH)-induced toxicity. The hepatoprotective salutation of SSEE (100 and $200 \mathrm{mg} / \mathrm{kg} . \mathrm{bw} /$ day) in carbon tetrachloride $\left(\mathrm{CCl}_{4}\right)$-intoxicated rats was evaluated by serum biochemistry and histopathology. The anti-oxidative activity of SSEE (31.25-500 $\mu \mathrm{g} / \mathrm{mL}$ ) was tested by 1,1-diphenyl-2-picrylhydrazyl (DPPH) radical-scavenging and linoleic acid bleaching assays. Also, SSEE was subjected to qualitative phytochemical analysis, and standardized by validated high-performance liquid chromatography (HPTLC).

Results: SSEE at doses 50, 100 and $200 \mu \mathrm{g} / \mathrm{mL}$ showed HepG2 cell proliferative and protective potential by about 61.0, 67.2 and $95 \%$, respectively through inhibition of caspase-3/7 against DCFH-toxicity. In CCl -injured rats, SSEE (200 mg/ $\mathrm{kg})$ significantly $(P<0.001)$ normalized serum transaminases, alkaline phosphatase, bilirubin, cholesterol, triglycerides, and total protein, including tissue malondialdehyde and nonprotein sulfhydryls levels, supported by the liver histopathology. SSEE further showed strong in vitro anti-oxidative and anti-lipid peroxidative activities, evidenced by the presence of alkaloids, flavonoids, tannins, sterols and saponins. Identification of $\beta$-sitosterol $(3.46 \mu \mathrm{g} / \mathrm{mg})$ strongly supported the anti-oxidative and hepatoprotective salutation of SSEE.
\end{abstract}

Conclusion: Our findings suggest the therapeutic potential of S. surattense against chemical-induced oxidative stress and liver damage. However, isolation of the active principles and elucidation of mechanism of action remain to be addressed.

Keywords: Solanum surattense, Hepatoprotection, Oxidative stress, Apoptosis, DCFH, CCl,$\beta$-sitosterol

\footnotetext{
* Correspondence: khalidparvez9@gmail.com; mohkhalid@ksu.edu.sa

${ }^{1}$ Department of Pharmacognosy, College of Pharmacy, King Saud University,

Riyadh, Saudi Arabia

Full list of author information is available at the end of the article
}

(c) The Author(s). 2019 Open Access This article is distributed under the terms of the Creative Commons Attribution 4.0 International License (http://creativecommons.org/licenses/by/4.0/), which permits unrestricted use, distribution, and reproduction in any medium, provided you give appropriate credit to the original author(s) and the source, provide a link to the Creative Commons license, and indicate if changes were made. The Creative Commons Public Domain Dedication waiver (http://creativecommons.org/publicdomain/zero/1.0/) applies to the data made available in this article, unless otherwise stated. 


\section{Background}

Liver links the digestive tract and general circulation, and plays a central role in nutrient metabolism, synthesis of functional proteins and detoxification of drugs and chemicals [1,2]. Liver is subjected to various diseases which may be metabolic, toxin/chemical-induced tissue inflammation or viral hepatitis $\mathrm{B} / \mathrm{C}$-associated cirrhosis and carcinomas. Chronic liver disease is the fifth most common cause of mortality, worldwide where the casualty rate is increasing despite of advances in therapeutics [2]. Therefore, there is an essential need to search for new anti-hepatitis and hepatoprotective agents [3]. Notably, despite the significant popularity of several mono and poly-herbal products for liver diseases [4], only few, including silymarin are approved [5].

In Saudi Arabia, about 100 species of medicinal plants have been documented, and of these $>35$ plants are used in traditional folk medicine for the treatment of liver disorders [6, 7]. However, most of these herbal preparations are not subjected to sustained scientific evaluation. Therefore, based on known Saudi traditional use and available literature, we recently screened over seventy plants, notably Acacia mellifera, Aerva javanica, Atriplex subrecta and Solanum surattense for their cytotoxic, growth stimulating, and anti-hepatitis B activities in cultured liver cells $[8,9]$. Of these, further investigation of A. mellifera [9], A. javanica [10] and A. subrecta [11] showed strong anti-oxidative and hepatoproective efficacy in cultured liver cells as well as in rodents.

S. surattense Burm F. (Solanaceae), a perennial herbaceous weed that grows in the south of Saudi Arabia, Farasan islands and India. It is traditionally used for treatment of fever, asthma, cough, toothache, sexual diseases and to promote female fertility [7, 12]. Moreover, ample of biological screenings of $S$. surattense revealed that it had a significant anti-fungal [13], anti-plasmodial [14], anti-hyperlipidemic [15] and anti-diabetic [16] efficacies. In addition, while $S$. surattense seeds aqueous extract has been shown to deplete the oxidative stress of cauda epididymal spermatozoa [17], its ethanol extract is recently shown to have diuretic activity [18] in albino rats. A rare $16 \beta-\mathrm{H}$ steroidal alkaloid saponin and six known saponins [19], including two new steroidal alkaloids, solanoside A1 and solanoside B2 have been isolated from $S$. surattense [20]. With this back ground information and in line with our recent findings [8-11], the present study extends further investigation of $S$. surattense for the antioxidative, anti-apoptotic and hepatoprotective potential.

\section{Methods}

Plant material collection and preparation of total ethanolextract

S. surattense was collected from Jazan, Saudi Arabia and authenticated by an expert taxonomist Prof. Mohammad
Yusuf at the College of Pharmacy, King Saud University, Riyadh, and a voucher specimen (no. 16386) was submitted at the college herbarium. The plant leaves were washed, air-dried, powdered (300 g), soaked in 70\% ethanol (Merck, Germany) for two days at room temperature (RT), and filtered through Whatmann filter paper No.1 (Whatmann, USA). The process was repeated twice in ethanol and the extracts were evaporated under reduced pressure at $4{ }^{\circ} \mathrm{C}$ (Rotary Evaporator; Buchi, Switzerland). The obtained semi-solid $S$. surattense total ethanolextract (SSEE; $31.5 \mathrm{~g}$ ) was stored at $-20^{\circ} \mathrm{C}$ until used.

\section{Drugs and compounds}

2,7-Dichlorofluorescein (DCFH; Sigma, USA) and carbon tetrachloride $\left(\mathrm{CCl}_{4}\right.$; Merc, Germany) was used to induce in vitro and in vivo hepatocytotoxicity, respectively. Silymarin (Sigma, USA) was used as standard hepatoprotective drug. Ascorbic acid (Sigma, USA), gallic acid (Fluka, USA) and $\beta$-sitosterol (Sigma, USA) were used as standard antioxidant agents.

\section{Human liver cell culture}

Human hepatoblastoma cells, HepG2 (Cat\# ATCC ${ }^{\circ} \mathrm{HB}$ 8065) were procured (American Type Culture Collection, VA, USA) and grown in T75 culture flasks (Corning, USA) at $37^{\circ} \mathrm{C}$ with $5 \% \mathrm{CO}_{2}$ supply. The complete culture medium, RPMI-1640 (Gibco, UAS) contained 10\% bovine serum (Gibco, USA) and $1 \mathrm{x}$ penicillin-streptomycin mix (HyClone Laboratories, USA).

In vitro hepatoprotective and apoptotic signaling assays HepG2 cells were seeded $\left(0.5 \times 10^{5}\right.$ cells/well, in triplicate) in a 96-well flat-bottom plate and grown over night. DCFH $\left(\mathrm{IC}_{50}: 100 \mu \mathrm{g} / \mathrm{mL}\right)$ was used as a chemical inducer of hepatocyte toxicity [9-11]. Four different doses of SSEE $(25,50,100$ and $200 \mu \mathrm{g} / \mathrm{mL})$ and DCFH were prepared using dimethyl sulfoxide (DMSO; $>0.1 \%$, final) and complete RPMI media. For hepatoprotection assay, the cultures were treated with DCFH $(100 \mu \mathrm{g} / \mathrm{mL})$ plus a dose of SSEE, including untreated and DCFH alone-treated controls. The cells were incubated for 48 $\mathrm{h}$, following MTT assay (TACS MTT Cell Proliferation Assay Kit, Trevigen, USA) as per the manufacturer's instruction, and the optical density (OD) was measured (Microplate Reader ELx800; BioTek, USA).

For anti-apoptotic assay, caspase-3/7 activation was measured (Apo-ONE-homogenous caspase-3/7 Assay Kit; Promega, USA) as per the supplied manual. Briefly, HepG2 toxicity was induced with DCFH as above, and treated with the four doses of SSEE for $48 \mathrm{~h}$. Caspase-3/ 7 reagent was added $(100 \mu \mathrm{L} /$ well $)$, incubated in dark at RT for $5 \mathrm{~h}$, and the OD was measured.

For both the assays, cell survival was determined using the equation: $\left[\left(O D_{s}-O D_{b}\right) /\left(O D_{c}-O D_{b}\right)\right] \times 100$ where $\mathrm{OD}_{\mathrm{s}}$, 
$\mathrm{OD}_{\mathrm{b}}$ and $\mathrm{OD}_{\mathrm{c}}$ are the optical density of sample, blank and negative control, respectively. Data were subjected to non-linear regression analysis (Excel software 10.0, Microsoft, CA, USA) and presented as \% cell survival in relation to the untreated control.

\section{Animals, experimental design and SSEE treatment}

Thirty male Wistar rats (200-220 g; 8-9 wks) obtained from the Experimental Animal Care Center (College of Pharmacy, KSU, Riyadh) were kept in polycarbonate cages in a temperature-controlled sterile chamber under $12 \mathrm{~h}$ dark/light cycle $\left(25 \pm 2{ }^{\circ} \mathrm{C}\right)$. After acclimatization, animals were randomized and divided into five groups (Group I-Group V; six each). Group I served as untreated control and orally administered with normal saline $(1.0 \mathrm{~mL})$. Group II, III, IV and V received $\mathrm{CCl}_{4}$ in liquid paraffin $(1: 1 ; 1.25 \mathrm{~mL} / \mathrm{kg} \cdot \mathrm{bw})$, intraperitoneally (i.p.). Groups III and IV were orally administered with SSEE at a dose of 100 and $200 \mathrm{mg} / \mathrm{kg} \cdot \mathrm{bw}$, respectively for three weeks. Group V was orally administered with silymarin $(10 \mathrm{mg} / \mathrm{kg} \cdot \mathrm{bw})$ [21] for three weeks. All animals were cared in compliance with the guidelines of the Ethics Committee of the Experimental Animal Care Society, King Saud University, Riyadh.

\section{Acute oral toxicity test}

Rats were divided into five groups (GI-V, six animal each), and acute oral toxicity was performed (G1: normal control; GII: $50 \mathrm{mg} / \mathrm{kg} . b w ;$ GIII: $100 \mathrm{mg} / \mathrm{kg} . b w$; GIV: $200 \mathrm{mg} / \mathrm{kg}$.bw and GV: $500 \mathrm{mg} / \mathrm{kg} . \mathrm{bw}$ ) using the limit test as per the OECD guidelines for acute toxicity test 401 [22]. Animals were observed continuously for $1 \mathrm{~h}$ and then for $4 \mathrm{~h}$ at $30 \mathrm{~min}$ intervals, for any gross behavioral change and general motor activities (eg., writhing, convulsion, response to tail pinching, gnawing, pupil size, fecal output, feeding behavior, etc.), followed by an additional $72 \mathrm{~h}$ observation for healthy survival.

\section{Blood collection and liver tissue preparation}

Animals were anesthetized with sodium pentobarbital (Sigma-Aldrich, Germany; $50 \mathrm{mg} / \mathrm{kg}$.bw; i.p.) and sacrificed by cervical dislocation following blood collection (21G syringe). The liver tissues were quickly dissected, washed (1x PBS), fixed (10\% neutral buffered formalin) for $72 \mathrm{~h}$, and processed overnight for dehydration and paraffin impregnation using Automatic Tissue Processor (Sakura, Japan). The specimens were embedded in paraffin blocks using Embedding Station (Sakura, Japan), cut into $4 \mu \mathrm{m}$ sections using Rotary Microtome (Leica-RM2245, Germany) and stained with H\&E (Hematoxylin \& Eosin).

\section{Estimation of liver enzymes and bilirubin}

Rats serum samples were subjected to biochemical analyses for the levels of serum alanine aminotransaminase (ALT; Reflotron GPT, Roche Diagnostics GmbH, Mannheim, Germany), spartate aminotransaminase (AST; Reflotron GOT, Roche Diagnostics GmbH, Mannheim, Germany), alkaline phosphatase (ALP; Reflotron ALP, Roche Diagnostics GmbH, Mannheim, Germany), $\gamma$ glutamyl transferase (GGT; Reflotron GGT, Roche Diagnostics GmbH, Mannheim, Germany) and bilirubin (BIL; Reflotron BIL, Roche Diagnostics GmbH, Mannheim, Germany), using Reflotron Plus Analyzer (Woodley Equipment Co., Ltd., UK).

\section{Lipid profiling}

The levels of serum triglycerides (TG; Reflotron TG, Roche Diagnostics $\mathrm{GmbH}$, Mannheim, Germany), total cholesterol (TC; Reflotron Cholesterol, Roche Diagnostics GmbH, Mannheim, Germany) and high-density lipoproteins (HDL; Reflotron HDL Cholesterol, Roche Diagnostics GmbH, Mannheim, Germany) were determined using Reflotron Plus Analyzer (Woodley Equipment Co., Ltd., UK). For each sample, very low-density lipoproteins (VLDL) and low-density lipoproteins (LDL) were determined using the standard formula: $V L D L=$ $T G / 5$ and $L D L=T C-(V L D L+H D L)$, respectively.

\section{Estimation of total protein}

The rats serum total protein (TP) level were analyzed using commercial kit (Crescent Diagnostics Kit, Jeddah, Saudi Arabia), and calculated $\left(T P=\left[O D_{\text {sample }} / O D_{\text {stan }}\right.\right.$ dard $\times$ Concentration of standard) where $\mathrm{OD}_{\text {sample }}$ and $\mathrm{OD}_{\text {standard }}$ are the optical density of sample and standard, respectively.

\section{Determination of tissue malondialdehyde}

The liver tissue malondialdehyde (MDA) was determined as described elsewhere [23]. Briefly, tissues were homogenized with Potter-Elvehjem Type-C Homogenizer (Thomas scientific Inc., USA) in ice-cold potassium chloride $(\mathrm{KCl} ; 0.15 \mathrm{M})$. The OD $(\lambda=532 \mathrm{~nm})$ was recorded and the MDA content (nmol/g wet tissue) was calculated with reference to a standard curve of the freshly prepared MDA solution.

\section{Estimation of tissue nonprotein sulfhydryls}

Liver tissue nonprotein sulfhydryls (NP-SH) concentrations were measured as described elsewhere [24]. Briefly, tissues were homogenized with Potter-Elvehjem Type-C Homogenizer (Thomas scientific Inc., USA) in ice-cold ethylenediaminetetraacetic acid (EDTA; $0.02 \mathrm{mM}$ ) and the OD $(\lambda=412 \mathrm{~nm})$ was measured after adding Ellman's reagent (DTNB, 5,5'dithio-bis-2-nitrobenzoic acid; $0.02 \mathrm{~mL}$ ). 


\section{Microscopy and histopathology}

Treated HepG2 cells were observed under an inverted microscope (Optica, $\times 40$ and $\times 100$ ) for any morphological changes at 24 and $48 \mathrm{~h}$. Liver histopathology was examined under OMX1200C Light Microscope (Nikon, Japan) at magnifications of $\times 200$ and $\times 400$, and images were recorded with mounted digital camera.

\section{1,1-diphenyl-2-picrylhydrazyl (DPPH) radical scavenging activity of SSEE}

The in vitro free-radical scavenging ability of SSEE against DPPH was evaluated quantitatively as described elsewhere [25] in a 96-well microplate [10, 11]. Briefly, the triplicated dose of $\operatorname{SSEE}(31.25,62.5,125,250$ and $500 \mu \mathrm{g} / \mathrm{mL}$ ) in a volume of $100 \mu \mathrm{L} /$ well was mixed with $40 \mu \mathrm{l}$ of DPPH $(0.2 \mathrm{mM}$ in methanol), including ascorbic acid (standard) and a solvent control. Following $30 \mathrm{~min}$ incubation at $25^{\circ} \mathrm{C}$, OD $(\lambda=517 \mathrm{~nm})$ was read and percent radical scavenging activity was calculated $\left[1-\left(O D_{\text {sample }} / O D_{\text {standard }}\right) \times 100\right.$, where $\mathrm{OD}_{\text {sample }}$ and $\mathrm{OD}_{\text {standard }}$ where $\mathrm{OD}_{\text {sample }}$ and $\mathrm{OD}_{\text {standard }}$ are the optical density of sample and standard, respectively].

\section{$\beta$-Carotene-linoleic acid bleaching assay of SSEE}

The in vitro anti-oxidant (anti-lipid peroxidation) activity was evaluated as described elsewhere [26] in a 96well plate $[10,11]$. Briefly, $0.25 \mathrm{mg} \beta$-carotene was first dissolved in $0.5 \mathrm{~mL}$ chloroform, and added to a $12.5 \mu \mathrm{g}$ linoleic acid and $100 \mathrm{mg}$ Tween-40 solution, following chloroform evaporation (Speed vacuum concentrator; Savant, Thermo Electron Co.). The resultant was immediately diluted to $25 \mathrm{~mL}$ with distilled water and shaken to form an emulsion. A $200 \mu \mathrm{L}$ aliquot/well was added to SSEE $(50 \mu \mathrm{L})$ or gallic acid $(500 \mu \mathrm{g} / \mathrm{mL})$, including a solvent control (all in triplicate). Following incubation at $50^{\circ} \mathrm{C}$ for $2 \mathrm{~h}$, OD $(\lambda=470 \mathrm{~nm})$ was read at $30 \mathrm{~min}$ intervals. The antioxidant activity was estimated using two methods: by plotting a kinetic curve of sample against time, and by estimating the percent inhibition of lipid peroxidation $\left(\left[O D s_{120}-O D c_{120} / O D c_{0^{-}} O D c_{120}\right] \times 100\right)$ where $A_{120}$ and $A_{120}$ are the optical density of the sample and control, respectively at $120 \mathrm{~min}$, and $\mathrm{OD}_{0}$ is the optical density of the control at $0 \mathrm{~min}$.

\section{Qualitative phytochemical screening}

The preliminary in vitro qualitative phytochemical screening of SSEE for major secondary metabolites, such as alkaloids, flavonoids, anthraquinones, tannins, saponins, sterols and cardiac glycosides was performed using standard procedures [27]. Briefly, for alkaloids $3 \mathrm{~mL}$ solution of SSEE was dissolved in hydrochloric acid $(\mathrm{HCl}$; $2 \%$ ) filtered, and added to Mayer's reagent prepared in distilled water ( $50 \mathrm{~mL}$, final volume) where formation of a yellow precipitate was the positive test. For flavonoids,
$5 \mathrm{~mL}$ SSEE solution was treated with drops of sodium hydroxide $(\mathrm{NaOH} ; 20 \%)$ where appearance of yellow color that turned colorless after addition of diluted hydrochloric acid was the confirmation. For tannins, $0.25 \mathrm{mg}$ SSEE dissolved in $10 \mathrm{~mL}$ water and mixed with several drops of ferric chloride $\left(\mathrm{FeCl}_{3} ; 5 \%\right)$ where development of a brown-green/blue-black color was the sign of positivity. For saponins, $0.5 \mathrm{mg}$ SSEE dissolved in 10 $\mathrm{mL}$ water was agitated vigorously to form a thick persistent froth presenting a positive result.

\section{Standardization of SSEE by validated high-performance thin layer chromatograpy}

The high-performance thin layer chromatography (HPTLC) method was developed and validated to standardize the 70\% SSEE as described elsewhere [28]. Briefly, HPTLC $\left(10 \times 10 \mathrm{~cm}\right.$ pre-coated silica gel $\mathrm{F}_{254}$ plate) was carried out using $\beta$-sitosterol as reference biomarker. Of the several mobile phases tried to get good resolution and separation of different compounds present in SSEE, hexane and ethyl acetate $(4: 6 ; \mathrm{v} / \mathrm{v})$ was selected as the best combination. The standard along with samples was applied on the HPTLC plate (CAMAG Automatic TLC Sampler-4), developed (CAMAG Automated Developing Chamber-2), and scanned $(\lambda=360 \mathrm{~nm}$; CAMAG TLC Scanner-3) for densitometric analysis.

\section{Statistical analysis}

Results were expressed as mean \pm S.E.M. Total variation present in a set of data was estimated by one-way analysis of variance (ANOVA) followed by Dunnet's-test (Excel 2010; Microsoft OK, USA). $P<0.05$ was considered significant.

\section{Results}

Hepatoprotective and anti-apoptotic effect of SSEE on cultured liver cells

Microscopic observation showed apoptotic effect of DCFH on HepG2 cells and morphological recovery in SSEE $(50,100$ and $200 \mu \mathrm{g} / \mathrm{mL}$ ) treated cells at 24 and $48 \mathrm{~h}$ (data not shown). While the MTT assay revealed attenuation of DCFH-toxicity by SSEE in a dosedependent manner by restoring the cells proliferation by about 61.0, 67.2 and 95\%, respectively (Fig. 1a), the anti-apoptotic signaling analysis showed inhibition of cellular caspase-3/7 activity by $\sim 33,68$ and $88 \%$, respectively (Fig. 1b).

\section{Therapeutic effects of SSEE on rat liver biochemical markers}

The acute toxicity test of SSEE (limit: $500 \mathrm{mg} / \mathrm{kg}$ ) showed healthy survival of the rats without any sign behavioral changes or toxicity. We therefore, utilized 100 and $200 \mathrm{mg} / \mathrm{kg} . \mathrm{bw}$ of SSEE as experimental doses. The 

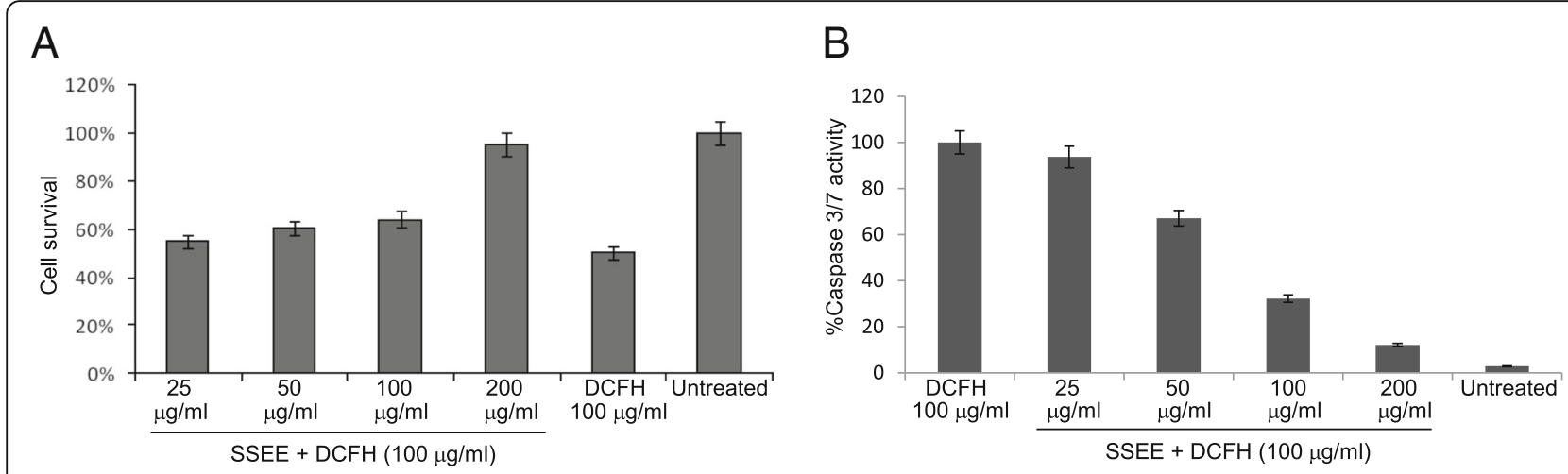

Fig. 1 In vitro protection of cultured HepG2 cells by S. surattense ethanol-extract (SSEE). a MTT Cell proliferation assay showing attenuation of DCFH-induced oxidative damage. $\mathbf{b}$ apoptotic assay showing inhibition of DCFH-induced caspase-3/7 activation

administration of $\mathrm{CCl}_{4}(1.25 \mathrm{~mL} / \mathrm{kg})$ drastically elevated the levels of AST, ALT, GGT, ALP, BIL, TC, TG, LDL, VLDL and MDA, and reduced HDL, TP and NP-SH contents compared to the untretaed control group, indicating liver injury while treatment with SSEE (100 and $200 \mathrm{mg} / \mathrm{kg})$ and silymarin (10 mg/kg.bw) significantly normalized $(P<0.001)$ these parameters as compared to the $\mathrm{CCl}_{4}$-only group (Table 1 ). The estimated hepatoprotective activity of SSEE on AST, ALT, ALP, GGT, BIL, TC, TG, LDL, VLDL, MDA, HDL, TP, and NP-SH (in order) was $2,14.2,7 \%, 15,16.2,13,21,13.3,20,7.2$, 5.7, 9.2 and $34.4 \%$ at $100 \mathrm{mg} / \mathrm{kg}$; and $10.8,30.7,15.3$, $30.7,27.3,18,35.7,32.7,36.6,43,30.55,31$ and $36.6 \%$ at $200 \mathrm{mg} / \mathrm{kg}$ whereas that of silymarin was $53.5,62.7,23,53.8,51,28,27,43.3,26.6,71.5,38.1$, 46.7 and $41.5 \%$, respectively (Table 1 ).

\section{Histological improvement by SSEE}

The histopathological analysis showed congested central vein, necrosis, inflammatory cells and vacuoles of fatty degeneration in $\mathrm{CCl}_{4}$-treated rats liver (Fig. 2; panel b) as compared to the normal tissue of control group (Fig. 2; panel a). Treatment with the higher dose of SSEE (200 $\mathrm{mg} / \mathrm{kg} . b w)$ (Fig. 2; panel c) or silymarin $(10 \mathrm{mg} / \mathrm{kg} . b w)$ (Fig. 2; panel d) effectively attenuated the $\mathrm{CCl}_{4}$-induced toxicity, and significantly normalized hepatocytes lesion and resulted in full recovery.

\section{In vitro antioxidant activity of SSEE}

Radical scavenging activities of SSEE were found to be $\sim 18.7,31.6,47.5,64.5$ and $83.3 \%$ at concentrations $31.25,62.5,125,250$ and $500 \mu \mathrm{g} / \mathrm{mL}$, respectively, as compared to ascorbic acid (Fig. 3a). In line with this,

Table 1 Therapeutic effect of SSEE against $\mathrm{CCl}_{4}$-induced hepatotoxicity related parameters in rats

\begin{tabular}{|c|c|c|c|c|c|}
\hline Liver function parameters & Gl (Control) & $\mathrm{GII}\left(\mathrm{CCl}_{4}\right.$-only) & $\mathrm{GIII}\left(\mathrm{CCl}_{4}+\right.$ SSEE $\left.100 \mathrm{mg}\right)$ & GIV $\left(\mathrm{CCl}_{4}+\right.$ SSEE $\left.200 \mathrm{mg}\right)$ & $\mathrm{GV}\left(\mathrm{CCl}_{4}+\right.$ Silymarin $\left.10 \mathrm{mg}\right)$ \\
\hline AST (U/L) & $107.45 \pm 5.31$ & $294.83 \pm 8.33^{* * *}$ & $288.50 \pm 7.36^{b}$ & $262.50 \pm 6.87^{b}$ & $136.66 \pm 6.00^{* * b}$ \\
\hline $\operatorname{ALT}(U / L)$ & $28.83 \pm 2.20$ & $230.83 \pm 9.62^{* * * a}$ & $198.16 \pm 7.12^{* b}$ & $159.50 \pm 9.17^{* * * b}$ & $85.66 \pm 4.31^{* * * b}$ \\
\hline $\operatorname{ALP}(\mathrm{U} / \mathrm{L})$ & $321.66 \pm 13.8$ & $515.16 \pm 13.7^{* * * a}$ & $479.00 \pm 6.12^{* b}$ & $436.33 \pm 12.31^{* * b}$ & $396.33 \pm 7.62^{* * * b}$ \\
\hline GGT (U/L) & $4.06 \pm 0.32$ & $12.85 \pm 0.98^{* * * a}$ & $11.38 \pm 0.49^{b}$ & $9.46 \pm 0.32^{* * b}$ & $5.58 \pm 0.28^{* * * \mathrm{~b}}$ \\
\hline BIL (mg/dL) & $0.54 \pm 0.01$ & $2.16 \pm 0.08^{* * * a}$ & $1.81 \pm 0.05^{* b}$ & $1.57 \pm 0.06^{* * * b}$ & $1.06 \pm 0.06^{* * * b}$ \\
\hline $\mathrm{TC}(\mathrm{mg} / \mathrm{dL})$ & $109.83 \pm 3.9$ & $206.00 \pm 4.53^{* * * a}$ & $179.50 \pm 6.63^{* * b}$ & $168.83 \pm 6.16^{* * *}$ & $147.66 \pm 4.88^{* * * b}$ \\
\hline TG (mg/dL) & $59.01 \pm 2.74$ & $151.16 \pm 4.61^{* * a a}$ & $119.33 \pm 3.8^{* * * \mathrm{~b}}$ & $96.81 \pm 3.75^{* * * \mathrm{~b}}$ & $110.16 \pm 5.26^{* * * b}$ \\
\hline $\mathrm{HDL}(\mathrm{mg} / \mathrm{dL})$ & $55.18 \pm 2.40$ & $25.25 \pm 1.79^{* * *}$ & $26.53 \pm 1.22^{b}$ & $36.28 \pm 1.78^{* * \mathrm{~b}}$ & $40.41 \pm 2.97^{* * \mathrm{~b}}$ \\
\hline LDL (mg/dL) & $42.84 \pm 3.22$ & $149.51 \pm 4.28^{* * * a}$ & $130.10 \pm 7.50^{* b}$ & $113.18 \pm 7.60^{* * b}$ & $85.21 \pm 5.98^{* * * b}$ \\
\hline $\operatorname{VLDL}(\mathrm{mg} / \mathrm{dL})$ & $11.80 \pm 0.54$ & $30.23 \pm 0.92^{* * * a}$ & $23.86 \pm 0.76^{* * * b}$ & $19.36 \pm 0.75^{* * * b}$ & $22.02 \pm 1.05^{* * * b}$ \\
\hline $\mathrm{TP}(\mathrm{g} / \mathrm{L})$ & $113.76 \pm 2.8$ & $49.11 \pm 1.82^{* * a}$ & $53.88 \pm 2.81^{b}$ & $71.452 .64^{* * * b}$ & $91.81 \pm 4.08^{* * * b}$ \\
\hline MDA (nmol/g) & $0.50 \pm 0.02$ & $4.82 \pm 0.29^{* * * a}$ & $4.47 \pm 0.23^{b}$ & $2.75 \pm 0.1^{* * * \mathrm{~b}}$ & $1.37 \pm 0.16^{* * * b}$ \\
\hline NP-SH (nmol/g) & $7.39 \pm 0.53$ & $3.86 \pm 0.44^{* * * a}$ & $5.79 \pm 0.35^{* * \mathrm{~b}}$ & $5.93 \pm 0.31^{* * b}$ & $6.52 \pm 0.31^{* * * b}$ \\
\hline
\end{tabular}

AST spartate aminotransaminase, ALT alanine aminotransaminase, ALP alkaline phosphatase, GGT $\gamma$-glutamyl transferase, BIL bilirubin, $T C$ triglycerides, HDL highdensity lipoproteins, $L D L$ low-density lipoproteins, VLDL very low-density lipoproteins, $T P$ total protein, MDA malondialdehyde, $N P$-SH nonprotein sulfhydryls. All values represent mean \pm SEM. ${ }^{*} P<0.05 ;{ }^{* *} P<0.01 ;{ }^{* * *} P<0.001$; ANOVA, followed by Dunnett's multiple comparison test. ${ }^{a}$ As compared with control group (Gl); ${ }^{\text {b } A s}$ compared with $\mathrm{CCl}_{4}$-only group (GII) 


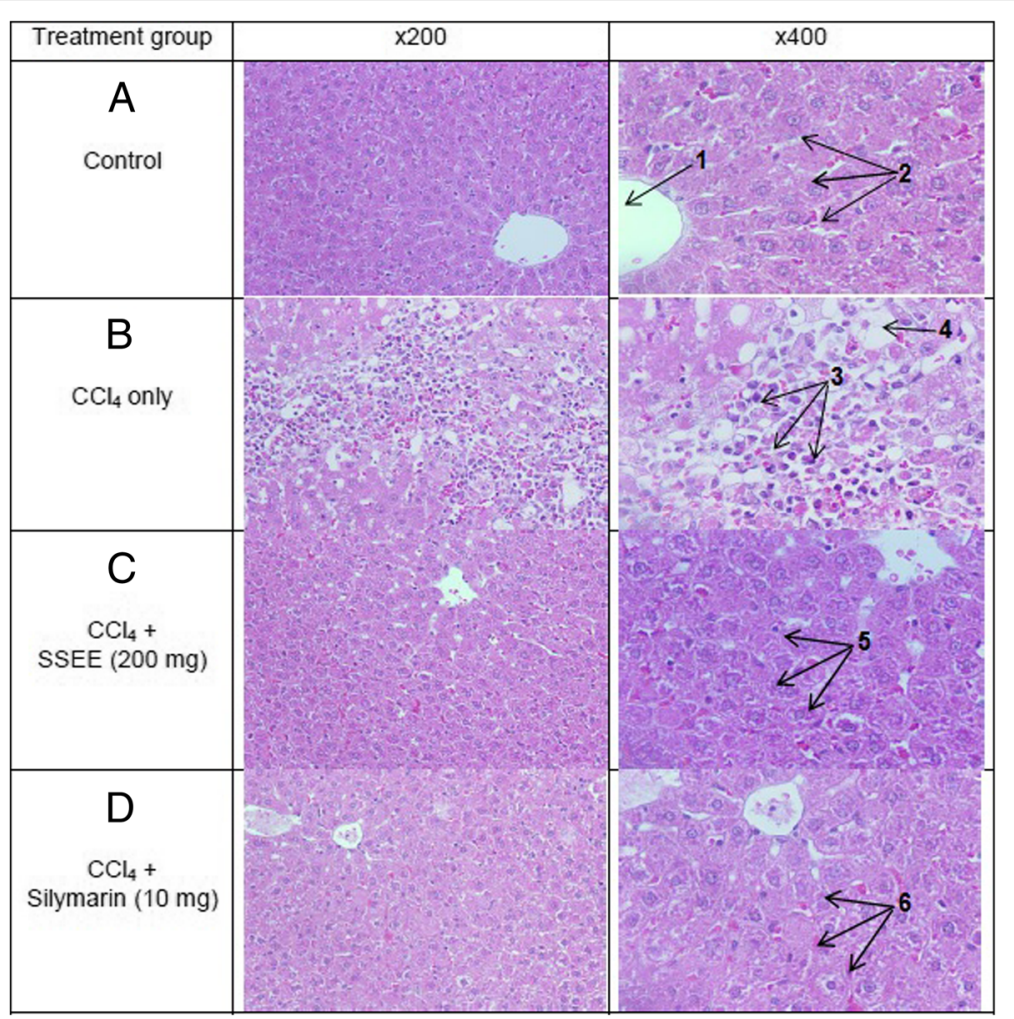

Fig. 2 Histopathology of experimental rat liver. Histograms showing (a) healthy tissues with normal central vein and hepatocytes; (b) $\mathrm{CCl}_{4}$-injured tissue with necrosis and fatty degenerative changes; (c) tissue with normal hepatocytes and central vein with full recovery after $\mathrm{CCl}_{4}$ plus $\mathrm{SSEE}$ (200 mg.kg.bw) treatment; and (d) tissue with normal hepatocytes and fully recovered central vein after $\mathrm{CCl}_{4}$ plus silymarin (10 mg.kg.bw) treatment. 1. Central vein; 2. Normal hepatocytes cord; 3 . Focal necrosis; 4 . Vacuoles of fatty degeneration; 5 . Normal hepatic tissue; 5 . Normal hepatic tissue

SSEE also showed dose-dependent anti-lipid peroxidation activity compared to gallic acid (Fig. 3b).

\section{Phytochemical screening}

Preliminary screening of SSEE indicated the presence of phytochemicals like, alkaloids, flavonoids, tannins, sterols and saponins but the absence of anthraquinones and cardiac glycosides (data not shown).

\section{Identification of $\beta$-sitosterol in SSEE}

Our HPTLC analysis identified $\beta$-sitosterol in SSEE as a compact spot at $R_{\mathrm{f}}=0.23$ (Fig. 4a, b), including good separations of different phytoconstituents (Fig. 4c, d). The estimated content of $\beta$-sitosterol was $3.46 \mu \mathrm{g} / \mathrm{mg}$ dry weight SSEE.

\section{Discussion}

Over 35 medicinal plants are traditionally used in Saudi Arabia to treat various liver disorders where majority still lack scientific validations. To address this issue, we have recently demonstrated the in vitro and in vivo therapeutic potential of A. mellifera [9], A. javanica [10] and $A$. subrecta [11] against chemical-induced toxicity and oxidative damage, including growth stimulating activity of
S. surattense on cultured HepG2 cells (unpublished data). To our knowledge, of the genus Solanum, the in vivo hepatoprotection by S. nigrum [29] and in vitro hepatoprotective as well as anti-oxidative effects of $S$. melongena [30] have been reported. The present study further investigated the healthprotective potential of genus Solanum and therefore, evaluated the anti-oxidative, anti-apototic and antihepatotoxic potential of S. surattense leaves ethanol extract (SSEE). Notably, the only in vitro study on S. surattense leaves extract has shown its anti-oxidative activity by DPPH free radical scavenging method [31].

In HepG2 cell culture model, we demonstrated the attenuation of DCFH-induced oxidative injury by SSEE in a dose-dependent manner. DCFH is generally used to measure in vitro oxidative stress generated by free radicals through the principle of oxidation of DCFH to the fluorescent DCF [32]. In addition, by exploiting DCFH as a potent cytotoxic agent in a panel of human cell lines, we have previously demonstrated protective salutations of several plant extracts or fractions against oxidative and apoptotic cell damages $[9-11,33,34]$. Moreover, by employing two different in vitro assays i.e., $\mathrm{DPPH}$ radical scavenging and linoleic acid bleaching methods, we showed the free radical attenuating and 
A

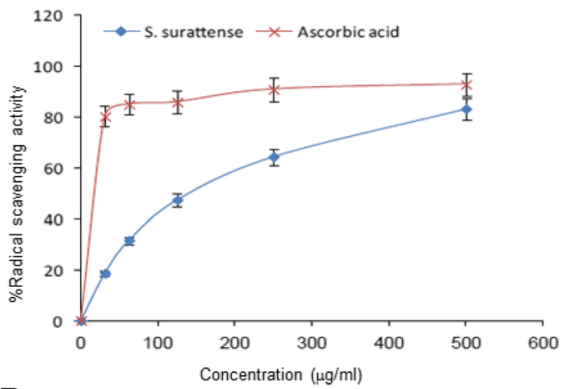

B
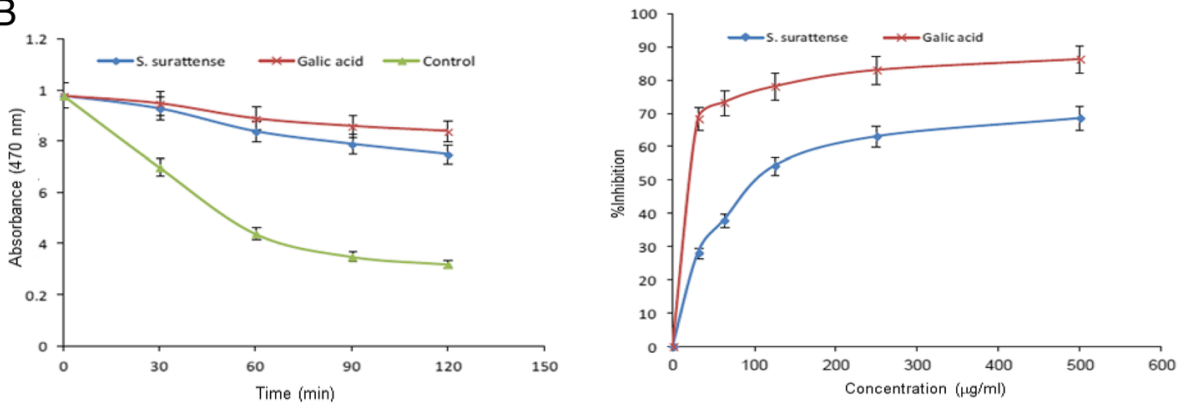

Fig. 3 In vitro antioxidant activity of S. surattense ethanol-extract (SSEE). a DPPH radical scavenging activity of different concentrations (31.25-500 $\mu \mathrm{g} / \mathrm{mL})$ of total ethanol extract of $S$. surattense and standard antioxidant (Ascorbic acid). $\mathbf{b} \beta$-carotene linoleic acid method showing $\beta$-carotene bleaching rate in presence of SSEE $(500 \mu \mathrm{g} / \mathrm{mL})$, gallic acid, blank control (left panel) and \%inhibition of lipid peroxidation by different concentrations of SSEE $(31.25-500 \mu \mathrm{g} / \mathrm{mL})$ and gallic acid (right panel)

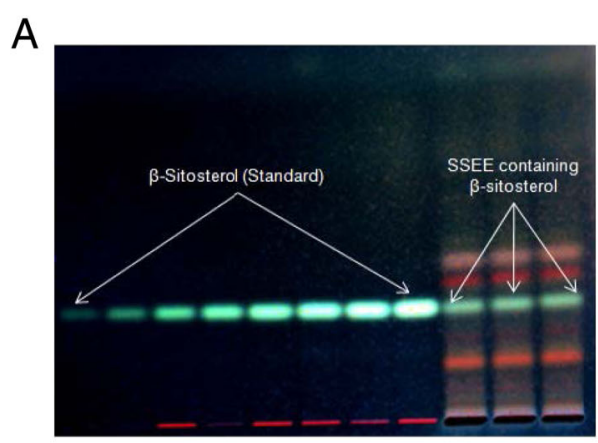

$\mathrm{C}$

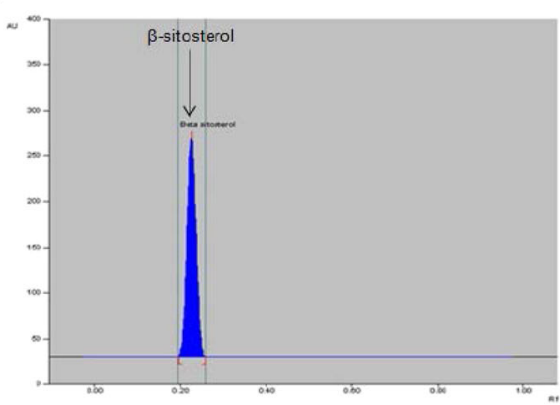

B
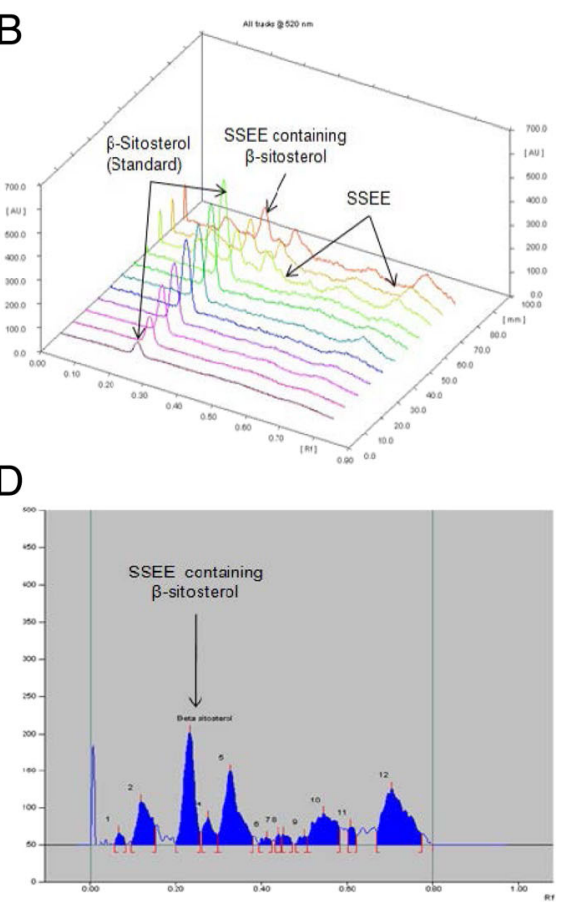

Fig. 4 HPTLC standardization of $\beta$-sitosterol in the $S$. surattense ethanol-extract (SSEE, $\lambda=360 \mathrm{~nm}$, mobile phase- hexane:ethyl acetate, 4:6, v/V). a chromatogram showing $\beta$-sitosterol biomarker (600 ng spot ${ }^{-1}$, peak 1, $R_{f}=0.23$ ); (b) chromatogram of SSEE containing $\beta$-sitosterol (peak 3 , $\left.R_{f}=0.23\right)$; (c) pictogram of developed and derivatized HPTLC plate of SSEE; (d) 3-D display of all tracks 
anti-lipid peroxidation potential of SSEE that further supported our data on HepG2 cells. Apoptotic cell death and inflammation by accumulation of endo/exogenous free radicals like reactive oxygen molecules are well known, where caspases (cysteine proteases) play essential roles [35]. Our anti-apoptotic signaling assay showed inhibition of DCFH-triggered cellular caspase- 3 and -7 activations by SSEE in a dose-dependent manner that reversed HepG2 cell apoptosis.

Further, in vivo hepatoprotective activity of SSEE in $\mathrm{CCl}_{4}$-induced experimental hepatitis was evaluated in rats by examining elevated serum liver enzymes and cellular necrosis and membrane permeability [36]. Significant elevations in levels of serum ALT, AST, BIL, TC, TG, LDL and VLDL, and reduction in HDL (indicative of hepatic injury) were observed in $\mathrm{CCl}_{4}$-injured rats where treatment with SSEE $(200 \mathrm{mg} / \mathrm{kg} . \mathrm{bw})$ or silymarin $(10 \mathrm{mg} / \mathrm{kg} . \mathrm{bw})$ markedly normalized these parameters, showing healing and recovery of liver damage. Serum MDA is a marker of cell membrane damages due to lipid peroxidation [37] that was elevated in $\mathrm{CCl}_{4}$-treated rats. SSEE administration also normalized MDA, suggesting its in vivo hepatoprotective and curative effect. In addition, the diminished liver NP-SH level in $\mathrm{CCl}_{4}$ treated groups, a marker of oxidative hepatocellular damage [38] was replenished by SSEE or sliymarin, indicating amelioration of liver damage. Also, the decreased level of TP in hepatotoxic condition was normalized by SSEE or silymarin in $\mathrm{CCl}_{4}$-injured rats, confirming its therapeutic ability. Furthermore, the histopathological analysis of liver tissues revealed the presence of normal hepatic cords and absence of necrosis and lesser fatty infiltration in SSEE supplemented rats against $\mathrm{CCl}_{4}$-induced lesions.

Moreover, the qualitative phytochemical screening of SSEE showed presence of anti-oxidant polyhenols, sterols, flavonoids and saponins wherein HPTLC analysis further identified $\beta$-sitosterol that had been previously reported to protect the liver against $\mathrm{CCl}_{4}$-hepatotoxicity via enhancing mitochondrial glutathione redox cycling [39]. Taken together, our in vitro and in vivo results clearly and convincingly demonstrated the anti-oxidative and anti-apoptotic salutation of S. surattense against two different chemicals/toxins induced liver injury that was in agreement with our earlier findings [9-11].

\section{Conclusions}

Our study of SSEE demonstrated its promising in vitro and in vivo anti-oxidative, anti-apoptotic and hepatoprotective potential against chemical-induced liver damage. This was further supported by phytochemical analysis as well as identification of $\beta$-sitosterol, a well-known antioxidant in SSEE. Probably the hepatoprotection by SSEE is due to multiple mechanisms involving the attenuation of the free radicals as well as apoptotic molecules, attributed to $\beta$-sitosterol. Our finding therefore, suggests therapeutic use S. surattense leaves as a source of dietary sterol in the prevention and treatment of chemical hepatitis and other chronic liver diseases. Nevertheless, further studies on novel active principles and their mechanism of action are warranted.

\begin{abstract}
Abbreviations
ALP: Alkaline phosphatase; ALT: Alanine aminotransferase; AST: Aspartate aminotransferase; $\mathrm{CCl}_{4}$ : Carbon tetrachloride; DCFH: 2,7-Dichlorofluorescein; DMSO: Dimethyl sulfoxide; DPPH: 1,1-diphenyl-2-picrylhydrazyl; HPTLC: High performance thin layer chromatographic; MDA: Malondialdehyde; MTT: 3(4,5-dimethylthiazol-2-yl)-2,5-diphenyltetrazolium bromide; SSEE: S. surattense ethanol extract; TP: Total protein
\end{abstract}

\section{Acknowledgments}

Technical help of Mr. Malik Saud (College of Pharmacy, King Saud University, Riyadh) in animal care is thankfully acknowledged.

\section{Authors' contributions \\ MKP conceptualized the study and design, performed cell culture experiment, supervised and analyzed all data, and prepared of the manuscript. MSA-D contributed in plant collection, phytochemistry and data analysis. AHA executed in vitro experiments and analyzed data. PA per- formed chromatography and analyzed data. MSA and AAK contributed in in vivo studies. All authors have read and approved the final manuscript.}

\section{Funding}

This study was financially supported by the Deanship of Scientific Research King Saud University, Riyadh (Research Group Project No. RG-1435-053). The funding body had no role in the design of the study; collection, analysis, and interpretation of data; and in writing the manuscript.

\section{Availability of data and materials}

The datasets used and analyzed during this study would be available upon request from the corresponding author.

\section{Ethics approval}

All animals used in this study were approved and were cared in compliance with the guidelines of the Ethics Committee of the Experimental Animal Care Society, King Saud University, Riyadh.

\section{Consent for publication}

Not applicable.

\section{Competing interests}

The authors declare that they have no competing interests.

\section{Author details}

'Department of Pharmacognosy, College of Pharmacy, King Saud University, Riyadh, Saudi Arabia. ${ }^{2}$ Department of Pharmacognosy, Faculty of Pharmacy, University of Khartoum, Khartoum, Sudan. ${ }^{3}$ Medicinal, Aromatic and Poisonous Plants Research Center, College of Pharmacy, King Saud University, Riyadh, Saudi Arabia. ${ }^{4}$ Department of Pharmaceutical Chemistry, College of Pharmacy, King Saud University, Riyadh, Saudi Arabia.

Received: 13 September 2018 Accepted: 7 June 2019

Published online: 03 July 2019

\section{References}

1. Williams R. Global challenges in liver disease. Hepatology. 2006;44:521-6.

2. di Bello G, Vendemiale G, Bellanti F. Redox cell signaling and hepatic progenitor cells. Eur J Cell Biol. 2018;97:546-56.

3. Khan I, Samson SE, Grover AK. Antioxidant supplements and gastrointestinal diseases: a critical appraisal. Med Princ Pract. 2017;26:201-17.

4. Aniya Y, Koyama T, Miyagi C, et al. Free radical scavenging and hepatoprotective actions of the medicinal herb, Crassocephalum crepidioides from the Okinawa Islands. Biol Phar Bul. 2005;28:19-23. 
5. Salam OMEA, Sleem AA, Omara EA, Hassan NS. Hepatoprotective effects of misoprostol and silymarin on carbon tetrachloride-induced hepatic damage in rats. Fund Clin Pharmacol. 2009;23:179-88.

6. Al-Asmari AK, Al-Elaiwi A, Athar MT, et al. A review of Hepatoprotective plants used in Saudi traditional medicine. Evid-Based Compl Alt Med. 2014; 2014:890842.

7. Rahman MA, Mossa JS, AISaid MS, Al-Yahya MA. Medicinal plant diversity in the flora of Saudi Arabia: a report on seven plant families. Fitoterapia. 2014; 75:149-61.

8. Arbab AH, Parvez MK, Al-Dosari MS, Al-Rehaily AJ. In vitro evaluation of novel antiviral activities of 60 medicinal plants extract against hepatitis B virus. Exp Ther Med. 2017;14:626-34.

9. Arbab AH, Parvez MK, Al-Dosari MS, Rafatullah S, Al-Sohaibani M, Zorag EA, Al-Rehaily AJ, Al-Said MS. Hepatoprotective and antiviral efficacy of Acacia mellifera leaves fractions against hepatitis B virus. BioMed Reh Intl. 2015; 2015:929131.

10. Arbab AH, Parvez MK, Al-Dosari MS, Al-Rehaily AJ, Ibrahim KE, Alam P, AlSaid MS, Rafatullah S. Therapeutic efficacy of ethanolic extract of Aerva Javanica aerial parts in the amelioration of $\mathrm{CCl}_{4}$-induced hepatotoxicty and oxidative damage in rats. Food Nutr Res. 2016;60:30864.

11. Parvez MK, Arbab AH, Al-Dosari MS, Al-Rehaily AJ, Alam P, Ibrahim KE, AlSaid MS, Rafatullah S. Protective effect of Atriplex suberecta extract against oxidative and apoptotic hepatotoxicty. Exp Ther Med. 2018;15: 3883-91.

12. Shahiladevi S, Jayanthi $G$, Jegadeesan M. Preliminary phytochemical studies on Solanum surattense burm.F. seeds. Anc Sci Life. 2006;26:59-64.

13. Jayanthi G, Anbazhakan S, Ramamoorthi R, Sundar R. Antifungal activity of Solarium surattense and Solanum melongena var. Insanum seeds. Plant Arch. 2008;8:343-4.

14. Ramazani A, Zakeri S, Sardari S, Khodakarim N, Djadidt ND. In vitro and in vivo anti-malarial activity of Boerhavia elegans and Solanum surattense. Malaria J. 2010;9:149-61.

15. Sridevi M, Kalaiarasi P, Pugalendi K. Antihyperlipidemic activity of alcoholic leaf extract of Solanum surattense in streptozotocin-diabetic rats. Asian Pacific J Trop Biomed. 2011;1:S276-80.

16. Kar DM, Maharana L, Pattnaik S, Dash GK. Studies on hypoglycaemic activity of Solanum xanthocarpum Schrad. \&amp; Wendl. fruit extract in rats. J Ethnopharmacol. 2006;108:251-6.

17. Thirumalai T, David E, Viviyan TS, Elumalai EK. Effect of Solanum surattense seed on the oxidative potential of cauda epididymal spermatozoa. Asian Pacific J Trop Biomed. 2012;2:21-3.

18. Swami H, Panigrahi MK, Pradhan S. Diuretic activity of ethanolic extract of plant Solanum surattense seeds. World J Pharm Res. 2017;6:835-40.

19. Lu YY, Luo J, Kong LY. Steroidal alkaloid saponins and steroidal saponins from Solanum surattense. Phytochemistry. 2011;72:668-73.

20. Nawaz H, Ahmed E, Sharif A, et al. Two new steroidal glycosides from Solanum surattense. Chem Nat Compd. 2014:49:1091-4.

21. Parveen R, Baboota S, Ali J, et al. Effects of silymarin nanoemulsion against carbon tetrachloride-induced hepatic damage. Arch Pharmacol Res. 2011;34: 767-74.

22. OECD. OECD guidelines for the testing of chemicals. Paris: Organization for Economic; 1994.

23. Utley $\mathrm{HG}$, Bernheim $\mathrm{F}$, Hochstein P. Effect of sulfhydryl reagents on peroxidation in microsomes. Arch Biochem Biophys. 1967;118:29-32.

24. Sedlak J, Lindsay RH. Estimation of total, protein-bound, and nonprotein sulfhydryl groups in tissue with Ellman's reagent. Anal Biochem. 1968;25: 192-205.

25. Lee $\mathrm{Y}$-J, Kim D-B, Lee J, Cho J-H, et al. Antioxidant activity and antiAdipogenic effects of wild herbs mainly cultivated in Korea. Molecules. 2013;18:12937-50

26. Miller HE. A simplified method for the evaluation of antioxidants. J Am Oil Chem Soc. 1971:48:91-8.

27. Satyajit D, Sarker D, Latif Z, Gray Al. Natural products isolation. 2nd edition ed. Totowa, New Jersey: Humana Press; 2006.

28. Parvez MK, Alam P, Arbab AH, Al-Dosari MS, Alqasoumi SI, Al-Howirini TA. Analysis of anti-oxidative and antiviral biomarkers $\beta$-amyrin, $\beta$-sitosterol, lupeol and ursolic acid in Guiera sengalensis leaves extract by validated HPTLC methods. Saudi Pharm J. 2018;26:685-93.

29. Tirkey N, Pilkhwal S, Kuhad A, Chopra K. Hesperidin, a citrus bioflavonoid, decreases the oxidative stress produced by carbon tetrachloride in rat liver and kidney. BMC Pharmacol. 2005;5:2-7.
30. Suhail M, Suhail S, Gupta BK, Bharat V. Malondialdehyde and antioxidant enzymes in maternal and cord blood, and their correlation in normotensive and Preeclamptic women. J Clin Med Res. 2009;1:150-07.

31. Babu BH, Shylesh BS, Padikkala J. Antioxidant and hepatoprotective effect of Acanthus ilicifolius. Fitoterapia. 2001;72:272-7.

32. Rota C, Chignell CF, Mason RP. Evidence for free radical formation during the oxidation of 2'-7'-dichlorofluorescin to the fluorescent dye 2'-7'dichlorofluorescein by horseradish peroxidase: possible implications for oxidative stress measurements. Free Radic Biol Med. 1999;27:873-81.

33. Shahat AA, Arbab AH, Al-Dosari MS, AI-Rehaily AJ, Alam P, Ibrahim KE, AlSaid MS, Rafatullah S. Treatment with Rhus tripartita extract curtails isoproterenolelicited cardiotoxicity and oxidative stress in rats. BMC Comp Alter Med. 2016;16:351.

34. Al-Yahya M, Raish M, AlSaid MS, Ahmad A, Mothana RA, Al-Sohaibani M, AlJenoobi FI, Al-Dosari MS, Parvez MK, Rafatullah S. 'Ajwa' dates (P. dactylifera L.) extracts ameliorates isoproterenol-induced cardiomyopathy through downregulation of oxidative, inflammatory and apoptotic molecules in rodent model. Phytomedicine. 2016;23:124.

35. Navarro VJ, Senior JR. Current concepts- drug-related hepatotoxicity. New Engl J Med. 2006;354:731-9.

36. Harvey NL, Kumar S. The role of caspases in apoptosis. Adv Biochem Eng Biotechnol. 1998:62:107-28.

37. Kedare SB, Singh RP. Genesis and development of DPPH method of antioxidant assay. J Food Sci Tech Mys. 2011;48:412-22.

38. Alam MN, Bristi NJ, Rafiquzzaman M. Review on in vivo and in vitro methods evaluation of antioxidant activity. Saudi Pharm J. 2013:21:143-52.

39. Wong HS, Chen JH, Leong PK, Leung HY, Chan WM, Ko KM. $\beta$-Sitosterol protects against carbon tetrachloride hepatotoxicity but not gentamicin nephrotoxicity in rats via the induction of mitochondrial glutathione redox cycling. Molecules. 2014;19:17649-61762.

\section{Publisher's Note}

Springer Nature remains neutral with regard to jurisdictional claims in published maps and institutional affiliations.

Ready to submit your research? Choose BMC and benefit from:

- fast, convenient online submission

- thorough peer review by experienced researchers in your field

- rapid publication on acceptance

- support for research data, including large and complex data types

- gold Open Access which fosters wider collaboration and increased citations

- maximum visibility for your research: over $100 \mathrm{M}$ website views per year

At BMC, research is always in progress.

Learn more biomedcentral.com/submissions 